\title{
Palaeoenvironmental Reconstruction in the Breydon Formation, Holocene of East Anglia
}

\author{
IAN BOOMER* \\ School of Environmental Sciences, \\ University of East Anglia, \\ Norwich. NR4 7TJ. U.K. \\ (*Present address, Institute of Earth Studies, University College \\ Wales, Aberystwyth, Dyfed, SY23 3DB. U.K.).
}

\author{
MIKE GODWIN \\ School of Environmental Sciences, \\ University of East Anglia, \\ Norwich. NR4 7TJ. \\ U.K.
}

\begin{abstract}
The foraminiferal and ostracod faunas from two East Anglian, Holocene cores are described. Together they add further environmental evidence to the lithological alternation between peat and alluvial mud sedimentation observed in these sections resulting from local changes in sea-level. Sedimentological and microfaunal differences between the two sections reflect their relative positions in the estuary with respect to the local palaeogeography. Foraminifera are abundant, the Ostracoda less so, nevertheless a comprehensive environmental interpretation is given and a foraminiferal ecological zonation proposed. Palaeoenvironmental reconstructions are based upon both microfossil groups which complement each other. J. Micropalaeontol., 12 (1): 35-46, August 1993.
\end{abstract}

\section{INTRODUCTION}

Recent investigations into the Holocene sediments of Central Broadland, west of Great Yarmouth, East Anglia, have provided a number of cores for sedimentological and palaeontological analysis. The cores were distributed over a wide area with a view to reconstructing local sea-level and palaeogeographical changes in the, post-glacial, marginal marine deposits of East Anglia. The sedimentary sequences recovered are dominated by estuarine and marine, fine grained, calcareous sediments, mainly clays and muds. In some areas coarser grained sands occur as localised channel fill deposits. Periods of regressive overlap during times of relatively low sea-level resulted in the deposition of peat.

Microfossils particularly the Foraminifera are generally abundant, the Ostracoda less so. An initial palaeoenvironmental reconstruction of these sediments, based upon their microfossil assemblages has been undertaken at the University of East Anglia (Coles, 1977). The present work details ostracod faunal change (I.B.) in two of these cores and combines that information with a foraminiferal ecological zonation based upon a comprehensive study of foraminiferal assemblages from a large numbers of Holocene sequences in this area (M.G.). These results have been used to refine the interpretation of sedimentological changes. The stratigraphical interval studied covers approximately the last six to seven thousand years.

East Anglia possesses a great number of modern, fresh and brackish water environments whose calcareous

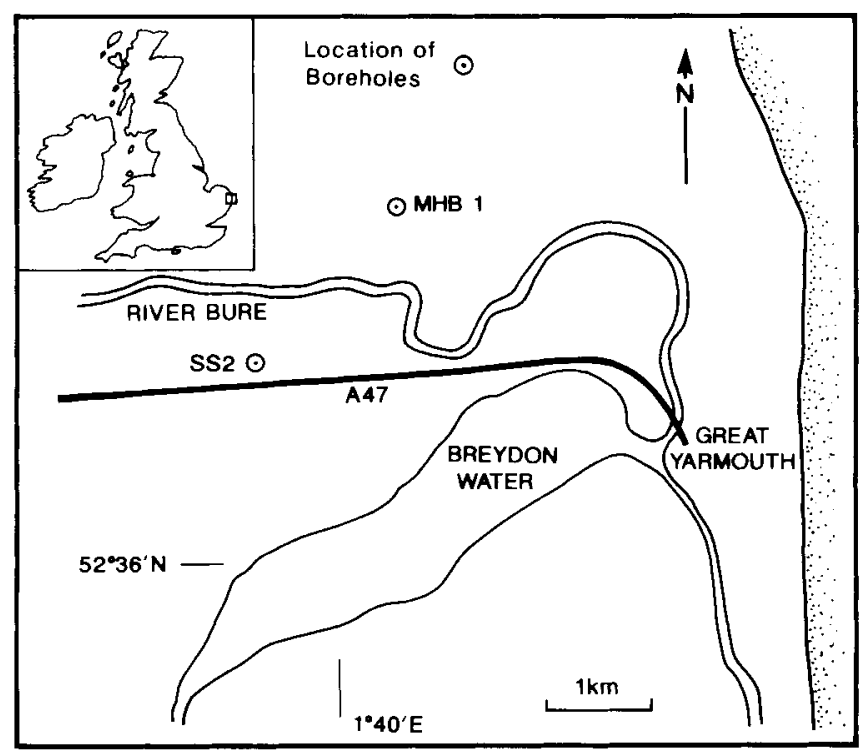

Fig 1. Location of Cores MHB1 and SS2.

invertebrate microfauna has not been studied in detail since the last century (Brady \& Robertson, 1870). All ostracod species recovered from the Holocene sediments still live in British waters, including the East Anglian region, today. Their preferred ecological niches are, generally, well known (Athersuch et al., 1989) and many of the ostracods have 
been collected by one of us (I.B.) as living specimens from the present day East Anglian estuaries during the course of this research. By combining this modern ecological information with the faunal composition of each assemblage it has been possible to provide a more detailed record of environmental changes within the sequence than could be afforded through the study of one microfossil group alone. No previous work has appeared on the Ostracoda of the Holocene deposits in this area.

\section{BACKGROUND}

The present work is a result of two separate research programmes undertaken at the University of East Anglia. The first, in association with the British Geological Survey, during remapping of the Yarmouth Geological Sheet recovered a number of cores through the Holocene sequence, thus providing a large sample base. The second project concerns the use of ostracod shell chemistry as a means of estimating salinity levels in a modern East Anglian estuary with a view to applying the technique to Holocene faunas, and in so doing, attempting to reconstruct past sea-level changes through the study of fossil shell chemistry. The results of that work, intended to supplement standard micropalaeontological results, appear elsewhere (Boomer, in press).

The Holocene deposits in this area are represented by a 10 to 25 metre thick sequence comprising three peat layers separated by two much thicker clay strata. The transgressive/regressive nature of the sedimentary succession means that the most complete sequences are found in the East of the study area. Agricultural methods have also led to the disturbance and/or removal of the youngest sediments in certain areas. This alternation in sediment type appears to reflect changes in effective sealevel in the area. Previous micropalaeontological and sedimentological investigations into these deposits were undertaken by Alderton (1983), Coles (1977), Coles \& Funnell (1981) and Funnell (1979). The interpretation of peat and clay alternations is thought to be a complex story involving changes in relative sea-level and development/destruction of spits and barriers across the estuary mouth. The average subsidence rate for the lower Yare Valley is estimated as averaging 1.5 metres every 1000 years since 9000 years B.P. The Holocene evolution of the
Suffolk estuaries has recently been studied (Brew, 1990; Brew et al. 1992) and their interpretation compared with the Yare Valley sequence to the north.

In their studies of the Holocene sediments underlying the lower Yare Valley and Halvergate Marshes Coles \& Funnell (1981) and Funnell (1979) described the occurrence of Lower, Middle and Upper Peats separated by a lower and an upper estuarine clay deposit. Their chronological interpretation of this sequence is given below in $14 \mathrm{C}$ years before present;

post c. 1500Upper Peat

c. 2000 to c. 1500 Upper Clay

c. 4500 to c. 2000 Middle Peat

c. 7500 to c. 4500 Lower Clay

pre 7500Lower Peat

The Upper and the Lower Peats were not encountered in the present study. The lowermost sediments in both sequences are represented by low intertidal Foraminifera and littoral to sub-littoral, phytal, marine Ostracoda. Thus, the transgressive transition from the 'non-marine' basal peat into 'littoral' conditions is missing. The layer of peat development encountered in both cores (i.e. the middle peat) was thought, by Coles and Funnell (1981), to have formed while the estuary mouth was effectively sealed by a coastal barrier, from about 4500 years ago. The second transgressive phase which, resulted in the deposition of the upper clay, was thought to have been initiated about 2000 years B.P. with its maximum influence at about 1600 years ago. The abrupt cessation of clay deposition at about 1500 years B.P. has been postulated as indicating the southward extension of the Great Yarmouth Spit across the mouth of the Bure-Yare-Waveney estuary system (Brew, 1990).

\section{SAMPLING}

The two sections currently under investigation were taken using a "Minuteman" power- driven rotary auger. Cores were retrieved using a block and tackle system, this coring and retrieval method leads to sediment disturbance so that no sedimentary structures were recorded. Sediment samples were taken off the corer in 20 centimetre intervals. Small sub- samples were taken for foraminiferal analysis ( $10 \mathrm{~g}$ for MHB1, $5 \mathrm{~g}$ for SS2) while somewhat larger samples (approximately 75g) were, generally, used for the ostracod studies. All samples were broken down using hydrogen

\section{Explanation of Plate 1}

All figured ostracod specimens and comparative Foraminifera specimens deposited at the British Museum (Natural History).

Fig 1. Cyprideis torosa (Jones) x44 (OS14160). Fig 2. Leptocythere castanea (Sars) x71 (OS14157). Fig 3. Hemicythere villosa (Sars) x70 (OS14153). Fig 4. Cytherois fisheri (Sars) $x 70$ (OS14154). Fig 5. Hirschmannia viridis (O.F. Muller) $\times 69$ (OS14155). Fig 6. Palmoconcha laevata (Norman) $x 71$ (OS14158). Fig 7. Palmoconcha guttata (Norman) x71 (OS14156). Fig 8. Loxoconcha rhomboidea (Fischer) x71 (OS14159). Fig 9. Trochammina inflata (Montagu) x91 (P52844). Fig 10. Jadammina macrescens (Brady) x101 (P52845). Fig 11. Miliammina fusca (Brady) x113 (P52846). Fig 12. Elphidium williamsoni Haynes x64 (P52847). Fig 13. Elphidium excavatum (Terquem) forma lidoensis Cushman x107 (P52848). Fig 14. Haynesina germanica (Ehrenberg) x112 P 52849. Fig 15. Ammonia beccarii (Linne) var batavus Hofker (Marsh creek specimen). x118 (P52857). Fig 16. Elphidium earlandi Cushman x137 (P52855). Fig 17. Elphidium magellanicum Heron-Allen and Earland x105 (P52854). Fig 18. Haynesina depressula (Walker \& Jacob) x124 (P52850). Fig 19. Elphidium macellum (Fichtel \& Moll) x64 (P52859). Fig 20. Elphidium excavatum (Terquem) forma clavata Cushman x110 (P52858). Fig 21. Ammonia beccarii (Linne) var batavus (Sub-tidal channel specimen). x65 (P52856). Fig 22. Elphidium margaritaceum Cushman x128 (P52853). Fig 23. Elphidium oceanensis (d'Orbigny) x151 (P52852). Fig 24. Elphidium excavatum (Terquem) forma magna Miller, Scott \& Medioli. x101. (P52851). 


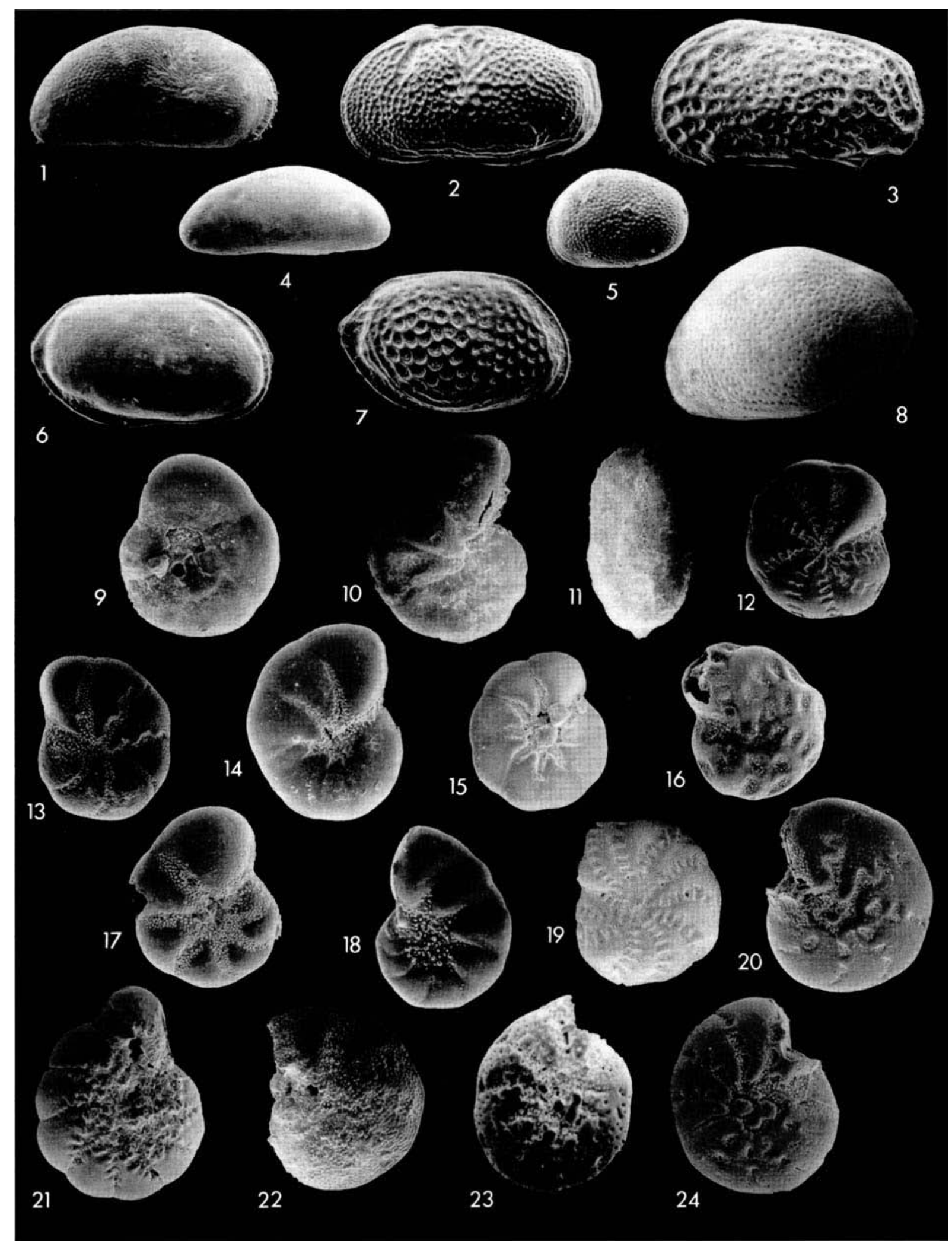


peroxide at room temperature for 24 hours. The resulting sediment was then washed to remove the mud (less than $635 \mathrm{~m}$ ) fraction, the final residue was often very small compared with the original sample size. These small samples, in some cases, yielded diverse ostracod faunas but low numbers of individuals which hampers the recognition of in situ and reworked/transported assemblages (this is particularly true for the upper part of core SS2 where only small samples were available). The palaeoenvironmental interpretation of a given sample is based, therefore, on the total aspect of the ostracod and foraminiferal fauna rather than the occurrence of one or two species unless they appear to be numerically important (i.e. relatively dominant) and in situ. In some cases assemblages were abundant but composed of one or two dominant species. Foraminifera are generally abundant in all samples recovered except where peats were encountered.

\section{Core MHB1.}

Core MHB1 was drilled on Mautby Marshes (Nat. Grid Ref. TG 4954 1054; Fig 1) and penetrated to a depth of just over 18 metres, twenty seven samples were taken altogether (figure 2). The base of the Breydon Formation was not reached in this core but adjacent boreholes show it to be 2122 metres below ground level in this area with a 1-2 metre thick oyster bed lying directly on the Pleistocene basement. These sediments are sub-tidal and are believed to have been deposited following a rapid transgression.

Table 1. Lithological description of core MHB1.

\section{Core SS2}

Core SS2 was drilled on Acle Marshes (Nat Grid Ref. TG 4815 0910; figure 3) to a depth of 17.8 metres, twenty seven samples were taken (figure 3 ). Core SS2 was much less varied in its lithology than MHB1. This is probably due to its palaeogeographical position, being in a more open part of the estuary and, therefore, less likely to have been subject to minor "sea-level" fluctuations than the marginally situated MHB1. The base of the Holocene sequence was not reached in this core and the nature of the basement in this area is not known. Some cores in this area exhibit crude laminations in intertidal flat and sub-tidal flat muds.

Table 2. Lithological description of core SS2.

\section{FORAMINIFERAL BIOZONES AND BIOFACIES OF THE BREYDON FORMATION}

In all, some 23 boreholes from the Holocene Breydon Formation of East Anglia have been studied for their foraminiferal content. An environmental zonation scheme has been established where the presence of both individual species and species assemblages are used to determine the relative tidal position of mean sea-level at the time of deposition.

\section{Foraminiferal Biozones}

Introduction. The present scheme is based upon the previous work in this region (Coles, 1977; Coles \& Funnell, 1981) and is expanded with new data from the present study. A complete revision of these studies is currently in preparation (Godwin, in prep. $a, b$ ) following the approach introduced by Scott \& Medioli $(1978,1986)$. Interpretation of the samples does not rely solely on the foraminiferal evidence. Average sediment grain size, plant remains, shell debris and Ostracoda are considered together with the size, condition and probable provenance of the foraminiferal tests with a view to assigning a sample to a given Zone. The Biozones refer to the depth of the environment relative to local, mean sea-level.

The definitions of Murray (1979) and Miller et al. (1982) are used for the identification of the ecomorphotypes of Ammonia beccarii and Elphidium excavatum respectively. The recognition of the variants of these two species is important in the scheme. The scheme can be summarised as follows:-

\section{ZONATION INDEX SPECIES.}

\section{Upper Saltmarsh.}

Zone IaT. inflata

Zone IbT. inflata, J. macrescens

Lower Saltmarsh

Zone IIa $T$. inflata, J. macrescens, $A$. beccarii vars limnetes/tepida, $H$. germanica, E. williamsoni.

Zone $\mathrm{IIb} A$. beccarii vars limnetes/tepida, $H$. germanica, $E$. williamsoni, E. excavatum forma lidoensis.

Zone IIcLarge $A$. beccarii together with some (Marsh Creeks) Miliolids and a mixture of mainly saltmarsh and some subtidal morphospecies.

High Intertidal Flat

Zone IIIaA. beccarii, $H$. germanica, E. excavatum formas excavata/selseyensis plus a small percent of small, size sorted E. earlandi, E. gerthi, E. magellanicum and other shelf species.

\section{Transition zone}

Zone IIIb A mixture of IIIa and IVa assemblages sub-tidal species becoming more important.

Tidal Flat Channel

Zone IIIc As for IIc but saltmarsh species are rarer, and small, size-sorted, transported shelf material more common. Low Intertidal Flat

Zone IVa A. beccarii, $H$. germanica, 4-10\% E. oceanensis and/or E. excavatum forma clavata.

Sub-tidal Flats, (b) and Channels (c)

Zone IVb/c A. beccarii, H. germanica, $11-50 \%$ E. oceanensis and/or E. excavatum forma clavata. Miliolids $H$. depressula \& E. incertum more common here than elsewhere.

The present study recognises only the Lower Saltmarsh through to Low Intertidal Zones.

The lower saltmarsh ( 0.8 to $0.6 \mathrm{~m}$ above mean sea-level). Zone IIa, the upper part of this Zone, is typically dominated by Phragmites reed stands. Assemblages contain 20-50\% textularids with Trochammina inflata and Jadammina macrescens being the most important species. Calcareous taxa constitute the remainder of the assemblage in Zone IIa but represent at least $90 \%$ of the, lower, Zone IIb. Diagnostic species are Haynesina germanica, Elphidium williamsoni, E. excavatum forma lidoensis, and $A$. beccarii vars limnetes and tepida. The ostracod $C$. torosa often reaches great abundance 
DEPTH

IN METRES

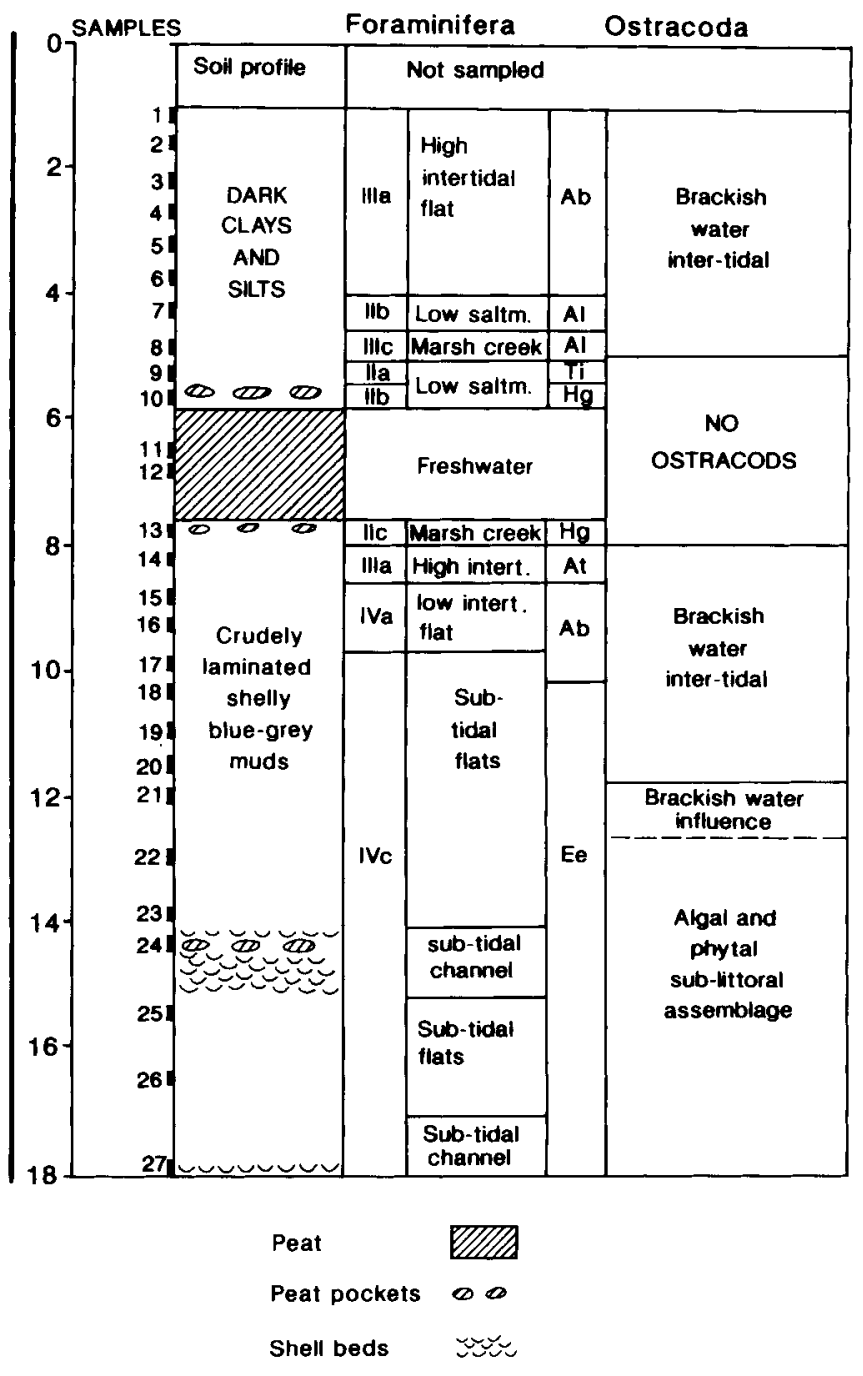

Fig 2. Lithological description and palaeoenvironmental interpretation of core MHB1.
DEPTH

CORE SS2

IN METRES

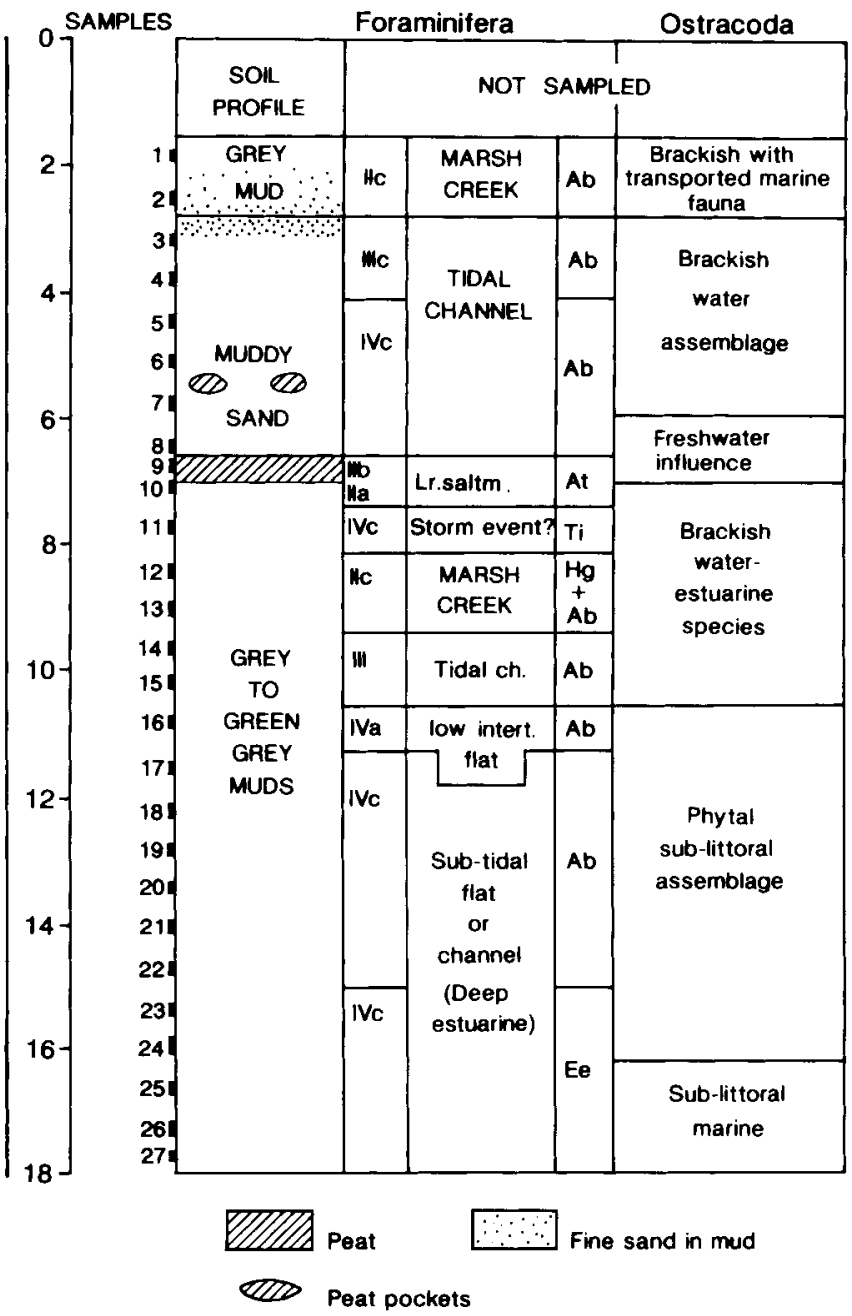

Fig 3. Lithological description and palaeoenvironmental interpretation of core SS2.

\begin{tabular}{|ll|}
\hline & \multicolumn{1}{c}{$\begin{array}{c}\text { TABLE 1 } \\
\text { Lithological description of Core MHB1 }\end{array}$} \\
Depth $(\mathrm{cm})$ & SEDIMENT DESCRIPTION \\
$0-97$ & Soil profile. \\
$98-190$ & Dark grey silty mud \\
$191-380$ & Very dark grey to black mud \\
$381-530$ & Dark grey silty mud \\
$531-534$ & Brown silty mud with sharp upper contact \\
$535-583$ & Brown silty mud with peaty pockets \\
$584-760$ & Amorphous brown peat, sulphurous smell, sharp upper contact, lower contact not observed. \\
$761-770$ & Blue grey silty Phragmites mud with patches of peat. \\
$771-1805$ & Shelly, blue grey silty mud with Scrobicularia plana and Cerastoderma lamarcki. Shell beds occur at depths \\
& of 1425, 1446-1520 and 1795-1805cm. Patchy peat packets are recorded at 1426-1445cm. \\
& \\
& \\
\hline
\end{tabular}




\begin{tabular}{|c|c|c|c|c|c|c|c|c|c|c|c|c|c|c|c|c|c|c|c|c|c|c|c|c|c|c|c|}
\hline SAMPLE & 1 & 2 & 3 & 4 & 5 & 6 & 7 & 8 & 9 & 10 & 111 & & 13 & 14 & 15 & 16 & 17 & 18 & 19 & 20 & 21 & 22 & 23 & 24 & 25 & 26 & 27 \\
\hline T.inf lata/J.macrescens/K. fusca & 0 & 1.6 & 0 & 1.5 & 2.8 & 1.8 & 2.6 & 0.5 & 45 & 4.3 & 0 & 0 & 0 & 1.8 & 1 & 0.3 & 0.5 & 0 & 0 & 0 & 0 & 0 & 00 & 0.5 & 0 & 0 & 0 \\
\hline A.becarii var limnetes & 0.4 & 0 & 0 & 0 & 1.4 & & 55.12 & 28.52 & 20.8 & 4.3 & 0 & 0 & 0 & 3.6 & 0 & 3.2 & 0.8 & 0.6 & 0.60 & 0.8 & 11 & 1.6 & 0.30 & 0.5 & 1 & 1.3 & 2.5 \\
\hline $\begin{array}{l}\text { E. williamsoni/E.excavatum } \\
\text { forma lidoensis }\end{array}$ & 2.4 & 3.1 & 0 & 1.5 & 1.4 & 2.6 & 8.9 & 2 & 2.11 & 10.6 & 0 & 0 & 0 & 4.4 & 1.5 & 4.2 & 2.7 & 0 & 0 & 0 & 10 & 0.8 & 0 & 0 & 0 & 0 & 0.3 \\
\hline P.germanicum & 27.32 & 23.42 & 25.42 & 22.72 & 24.22 & 26.31 & 17.72 & 28.31 & 19.84 & 48.9 & 0 & 0 & 504 & 43.2 & 283 & 35.73 & 35.82 & 29.822 & 22.523 & 3.622 & 2.222 & 22.318 & 18.114 & 4.6 & 9.718 & 8.71 & 11.8 \\
\hline A.beccarii var tepida & 0 & 0 & 0 & 0 & 1.1 & 0 & 6.3 & 8.3 & 5.42 & 21.3 & 0 & & 28.62 & 23.8 & 252 & 21.31 & 17.51 & 19.7 & 1918 & 8.423 & 3.829 & 29.731 & 31.333 & 3.34 & 46.82 & 7.3 & 36 \\
\hline A. becarii var batavus & 44.95 & 53.14 & 48.35 & 53.24 & 49.85 & 51.8 & & 19.7 & 3.3 & 6.4 & 0 & & 14.31 & 16.2 & 322 & 25.82 & 22.62 & 26.227 & 27.627 & 7.319 & 9.819 & 19.6 & 2719 & 9.31 & 15.32 & 24.22 & 20.9 \\
\hline $\begin{array}{l}\text { E.gerthi/E.earlandi/E.magellanicum } \\
\text { E.excavatum formas excavatum/ } \\
\text { selseyensis }\end{array}$ & 221 & & 181 & 15.31 & 14.71 & 15.9 & & 11.1 & 3.3 & 4.2 & 0 & 0 & 7.1 & 5.1 & 1 & 1.2 & 0.2 & 0.6 & 0 & 0 & 0 & 0 & 0 & 0 & 0 & 0 & 0.3 \\
\hline $\begin{array}{l}\text { E.oceanensis/E.excavatum forma } \\
\text { clavata }\end{array}$ & 0 & 0 & 0 & 0 & 0 & 0 & 0 & 0 & 0 & 0 & 0 & 0 & 0 & 0 & 9.5 & & 17.42 & 21.930 & 30.229 & 9.629 & 9.42 & 24.3 & & 99.32 & 26.22 & 25.32 & 25.2 \\
\hline $\begin{array}{l}\text { E.margaritaceum/E.crispum/macellum } \\
\text { E.excavatum forma magna }\end{array}$ & 1.2 & 1.6 & 3.3 & 2 & 1.1 & 0 & 0 & 0.5 & 0 & 0 & 0 & 0 & 0 & 0 & 0 & 0 & 0 & 0 & 0 & 0 & 0 & 0 & 0 & 0 & 0 & 0 & 0 \\
\hline H.depressula/R.incertum & 0.8 & 0 & 3.4 & 1.5 & 1 & 0.6 & 0.7 & 0.5 & 0 & 0 & 0 & 0 & 0 & 1.1 & 2 & 2.3 & 1.1 & 0 & 0.90 & 0.3 & 0.7 & 0.9 & 0.62 & 2.5 & 0 & 0 & 0.3 \\
\hline SHELF ROTALIDS & 0 & 1.6 & 1.6 & 3.4 & 1.8 & 0 & 0 & 1 & 0 & 0 & 0 & 0 & 0 & 0 & 0 & 0 & 0 & 0 & 0 & 0 & 0 & 0 & 0 & 0 & 0 & 0 & 0 \\
\hline MILIOLIDS & 0.8 & 0 & 0 & 0 & 0.7 & 0.6 & 0.6 & 0 & 0 & 0 & 0 & 0 & 0 & 0 & 0 & 0 & 0.2 & 0 & 0 & 0 & 0 & 0.8 & 0.6 & 1 & 0.9 & 3.2 & 2.7 \\
\hline Planktonics/Cretaceous fossils & 0 & 0 & 0 & 0 & 0 & 0 & 0 & $\mathbf{0}$ & 0 & 0 & 0 & 0 & 0 & 0 & $\mathbf{0}$ & 0 & o & 0 & 0 & 0 & 0 & 0 & 0 & 0 & 0 & 0 & $\mathbf{0}$ \\
\hline $\begin{array}{l}\text { Total specimens in } 10 \mathrm{~g} \\
\text { Total number of morphospecies }\end{array}$ & $\begin{array}{r}245 \\
11\end{array}$ & $\begin{array}{r}128 \\
9\end{array}$ & $\begin{array}{r}122 \\
9\end{array}$ & $\begin{array}{r}203 \\
13\end{array}$ & $\begin{array}{r}281 \\
20\end{array}$ & $\begin{array}{r}170 \\
10\end{array}$ & $\begin{array}{r}158 \\
10\end{array}$ & $\begin{array}{r}207 \\
12\end{array}$ & $\begin{array}{r}91 \\
8\end{array}$ & $\begin{array}{r}47 \\
7\end{array}$ & $\begin{array}{l}0 \\
0\end{array}$ & $\begin{array}{l}0 \\
0\end{array}$ & $\begin{array}{r}14 \\
4\end{array}$ & $\begin{array}{r}279 \\
10\end{array}$ & $\begin{array}{r}202 \\
10\end{array}$ & $\begin{array}{r}342 \\
12\end{array}$ & $\begin{array}{c}3601 \\
11\end{array}$ & $\begin{array}{l}50010 \\
10\end{array}$ & $\begin{array}{c}00013 \\
7\end{array}$ & $\begin{array}{r}3006 \\
7\end{array}$ & $\begin{array}{r}600 \\
8\end{array}$ & $\begin{array}{r}224 \\
9\end{array}$ & $\begin{array}{c}65018 \\
10\end{array}$ & $\begin{array}{r}1800 \\
11\end{array}$ & $\begin{array}{r}950 \\
7\end{array}$ & $\begin{array}{c}5002 \\
7\end{array}$ & $\begin{array}{r}2200 \\
15\end{array}$ \\
\hline
\end{tabular}

Fig 4. Foraminiferal biostratigraphy of core MHB1 (per cent abundance).

\section{TABLE 2}

\section{Lithological description of Core SS2}

Depth (cm)

$0-156$

$156-280$

280-658

658-693

693-1794

\section{SEDIMENT DESCRIPTION}

Soil profile.

Light grey very soft mud, grading down into sand.

Grey, fine sand at top becoming muddy sand down-core. Peat patches at $540 \mathrm{~cm}$.

Brown compact peat.

Light grey/blue soft mud, grades downwards into grey, then dark grey and finally a green grey mud at $1758 \mathrm{~cm}$.

\section{TABLE 3}

\section{Summary of Biofacies Scheme}

\section{Biofacies}

$\mathrm{Ti}$

$\mathrm{Hg} / \mathrm{Al}$

$\mathrm{Hg}-\mathrm{Lr}$

At $/ \mathrm{Ab}$
Marker species

(T. inflata)

(H. germanicalA.beccarii Al - var limnetes)

H. germanica

( $A$. beccarii var tepida

A. beccarii var batavus)
Environment

Ur to Lr Saltmarsh.

Lr Saltmarsh

Saltmarsh to Tidal flat

Lr Saltmarsh to

Sub-tidal channels 
in this zone.

Marsh creeks (Zone IIc) and intertidal channels (IIIc), which are largely sub-tidal, display a mixture of saltmarsh and deeper water Foraminifera. Large specimens of $A$. beccarii var batavus, miliolids and the ostracod $C$. torosa are diagnostic of these zones. A rare ecomorphotype of $A$. beccarii var limnetes which has an umbilical boss also occurs in these environments. The sediments here tend to be sandier and the population density may be low.

Intertidal flats $(0.4 \mathrm{~m}$ above to $1.7 \mathrm{~m}$ below mean sealevel). Zone IIIa (High Intertidal Flat) assemblages are mainly composed of $H$. germanica and $A$. beccarii. Small, size-sorted specimens of $E$. earlandi, $E$. gerthi, $E$. magellanicum, E. margaritaceum and various exotic shelf species constitute a small but consistent faunal element in most assemblages. Forma excavata and selseyensis dominate the ecomorphotypes of E. excavatum in this Zone. Molluscan debris and Phragmites remains are rare in this environment but mineral grains of coal, muscovite mica and framboidal pyrite are generally common in these crudely laminated muds.

Zone IVa (Low Intertidal Flat) is diagnosed by the presence of $4-10 \%$ E. oceanensis and/or E. excavatum forma clavata. Assemblages are otherwise similar to zone IIIa except that shelf species are less important but, where they are recorded, tend to be larger than average. Typically, subassemblages of E. gerthi, E. crispum-macellum, E. margaritaceum and the rare E. excavatum forma magna dominate the transported element of the assemblage and range down into Zone IVc. Ostracoda, where abundant, are dominated by Loxoconcha spp. and/or Hemicythere villosa.

Sub-tidal flats and channels (more than $1.7 \mathrm{~m}$ below mean sea-level). Zone IVc assemblages (as defined by Banner \& Culver, 1978) constitute a range of test sizes, from juvenile to adult, of the sub-tidal species $E$. oceanensis, E. excavatum forma clavata and $A$. beccarii or $H$. germanica still dominate most populations, and sediments are generally quite shelly. Sub-tidal channels contain the large specimens referred to above in Zones IIc-IIIc and many assemblages consist of up to $100 \%$ A. beccarii. H. germanica and miliolids are the most common accessory species in this environment.

\section{Foraminiferal Biofacies}

Four distinct Biofacies have been identified which are much wider ranging zones than the depth controlled Zones referred to above. The biofacies reflect not only depth but also salinity, energy of the environment, substrate type and temperature. This scheme follows the 'associations' of Murray (1991). The Biofacies are named after the dominant or diagnostic species in each assemblage.

Additional ecological information for the key taxa is derived from Coles (1977), Coles \& Funnell (1981), Culver \& Banner (1978), Murray (1971, 1973, 1979), Murray \& Hawkins (1976), Miller et al. (1982) and Banner \& Culver (1978). Much of the information regarding salinity and temperature tolerance is summarised in Murray (1991). The present Biofacies scheme is summarised in table 3 .

Biofacies identified in the present study.

Trochammina inflata Biofacies (Ti). Range: Upper to Lower
Saltmarsh. Salinity: 0-35 ppt (generally brackish). Energy of environment: Low. Sediment type: Phragmites mud. Temperature: $0-30^{\circ} \mathrm{C}$.

Haynesina germanica/Ammonia beccarii var limnetes Biofacies (Hg/Al). Range: Al - Lower saltmarsh; Hg - Lower Saltmarsh to Sub-tidal Flat. Salinity: 0-15 ppt (brackish). Energy of environment: Low. Sediment type: Phragmites or estuarine muds. Temperature: $0-20^{\circ} \mathrm{C}$.

C Ammonia beccarii var tepida/Ammonia beccarii var batavus Biofacies (At/Ab). Range: Lower Saltmarsh to subtidal channels. Salinity: At - brackish, Ab - brackish to marine. Energy of environment: Medium to high. Sediment: Muds and sands. Temperature: $0-20^{\circ} \mathrm{C}$.

C. Elphidium excavatum - Elphidium oceanensis Biofacies (Ee). Range: Sub-tidal. Salinity: Brackish. Energy of environment: Medium to high. Sediment: Shelly estuarine muds. temperature: $0-20^{\circ} \mathrm{C}$.

\section{Microfossil assemblages from core MHB1.}

The sediments at the base of the core (17- 27) are characterised by foraminiferal assemblages belonging to the ' $\mathrm{Ee}^{\prime}$ Biofacies and, therefore, to the IVC sub-tidal Biozone (Fig 2). The dominant species is A. beccarii (50-60\%) with roughly equal proportions of marine and brackish water morphotypes present. Few tests show evidence of transportation from inner estuarine areas or from the estuary mouth although miliolids become relatively common towards the base of the core. The assemblages suggest medium energy levels and brackish salinity prevailing at this time. Water temperatures may have been lower than at later times suggested by the abundance of $E$. excavatum forma clavata (Murray, 1991). Further cores in this area suggest that the estuary was of the 'drowned valley' type in Lower Clay times (Godwin, in prep a). The foraminiferal and ostracod biostratigraphy of this core is given in figures 4 and 5, The most abundant and/or environmentally significant taxa are figured in plate 1.

The lowermost samples $(27-25)$ are dominated by assemblages of the ostracods $H$. villosa and $L$. rhomboidea. These are essentially algal and phytal feeders respectively. The former species decreases markedly at sample 25 with the subsequent samples (24-21) dominated by L. rhomboidea. Another loxoconchid, the marine species $P$. guttata, is common in the lower part of core SS2 but is only represented by a few specimens in the Lower Clay of core MHB1. Samples 21-20 see a decrease in L. rhomboidea with an increase in the importance of the brackish water species $C$. torosa and $L$. castanea. This clearly represents an increased freshwater influence. This pattern continues from sample 19 through to 14 with these two species eventually representing the only Ostracoda at the top of the Lower Clay as diversity decreases.

Samples 16-14 indicate a rapidly shallowing environment. Silting up of the estuary was probably aided by the barring of the estuary mouth by a sand spit (Coles \& Funnell, 1981). Samples 15-16 have 6-9.5\% E. oceanensis and are interpreted as low intertidal flat, Zone IVa. By sample 14 this component is absent and shallow water species have 
increased importance suggesting a high intertidal flat Zone IIIa assemblage. This regressive sequence belongs to the ' $\mathrm{Ab}$ ' Biofacies.

At the level of samples 13-14 there is a major change in the sediment type with shell debris replaced by Phragmites red material. There is a fall in diversity and abundance which is indicative of saltmarsh and marsh creek environments. The assemblages are placed in the marsh creek Zone IIc due to the presence of large specimens of $A$. beccarii var batavus, typical of channel faunas. It is inferred that the channel has cut into the intertidal flat sediments below. Samples 11-12 are barren peats witnessing the culmination of the regressive phase of deposition. The interval covered by samples 13-9 represents the Middle Peat and no Ostracoda are recorded from these levels. The two samples immediately above the peat, 6 and 8 (sample 7 was not investigated for ostracods) possess specimens of $H$. rubida, Xestoleberis sp. and $L$. castanea. There does not appear to be any evidence of a gradual increase in salinity in the ostracod faunas immediately following the peat development. This would support the suggestion that the top of the peat is an erosion layer (Godwin in prep a) marking the sharp onset of a transgressive phase in the Upper Clay. Samples 7-10 belong to the Lower saltmarsh Zones although channel migration has led to the presence of erosive surfaces adding further complexities to this part of the sequence. These samples are assigned to the ' $\mathrm{Hg}$ ' foraminiferal Biofacies. Sample 10 has $10 \%$ E. williamsoni, diagnostic of the Lower saltmarsh Zone IIb. This environment shallowed further in sample 9 with $45 \% \mathrm{~T}$. inflata and $J$. macrescens indicating a IIa level in the ' $\mathrm{Ti}$ ' Biofacies. The sediments were then cut by a channel (seen in sample 8 ), with Zone IIc faunas containing $19 \%$ A. beccarii var batavus and accessory, transported, shelf material. This feature had silted up by sample 7 represented by Zone IIb faunas in the ' $\mathrm{Al}^{\prime}$ Biofacies.

Samples 1-7 show the transgression regaining momentum and the entire sequence is interpreted as a high intertidal flat Zone IIIa lying in the 'At' Biofacies. Assemblages contain a small percentage of Elphidium species and small, size sorted, shelf taxa. Samples 5-2 are dominated by the brackish water ostracod $L$. castanea with a few specimens of phytal estuarine Ostracoda as accessory species. The uppermost sample (MHB1-1) contains assemblages of $L$. castanea, L. lacertosa and C. fisheri the latter two species are tolerant of fluctuating salinity levels and therefore represent a marginal setting within the estuary. The final evidence of silting up is lost in the soil profile.

Table 3. Summary of Biofacies Scheme.

\section{Microfossil assemblages from core SS2}

The initial transgressive phase (samples 17-27) is similar to the basal part of core MHB1 and is interpreted as sub-tidal mudflats (Zone IVc). The ' $\mathrm{Ee}^{\prime}$ Biofacies is not as fully developed as in MHB1 and there are higher numbers of exotic Foraminifera. A. beccarii var batavus is the dominant species and suggests higher salinities here than at the more marginally positioned MHB1 site. The foraminiferal and ostracod biostratigraphy for this core is given in Figs 6 and 7.

The lowermost samples of this core (27-25) are dominated by two species of Palmoconcha, P. guttata and P. laevata, only a few of the former species and none of the latter were recorded in the other core. These represent sub-littoral marine assemblages. samples 24 through to 16 are dominated by the phytal $L$. rhomboidea a common shallow sub- littoral species with secondary species such as $H$. villosa, $H$. viridis, $C$. torosa and $L$. castanea important at certain levels. The latter two species are recorded in many samples throughout the two cores. Although they may constitute a large percentage of some samples, analysis of their population structure would suggest that they are often transported from the shallower water, brackish regions of the estuary.

The regressive phase with abrupt shallowing and low intertidal flat taxa (sample 16) gives way to channel faunas with relatively high numbers of sub-tidal species. These assemblages are still within the ' $A b$ ' Biofacies indicating higher salinity levels persisting. Textularids are common in some of the marsh creek (Zone IIc) material. Sample 11, a thin sand, has a IVc sub-tidal fauna and is thought to represent a storm event. The sequence ends with a Phragmites mud in the ' $\mathrm{Ti}^{\prime}$ Biofacies and Ila lower saltmarsh Zone capped by a much eroded remnant of the Middle Peat. Ostracod assemblages from samples 15 to 9 indicate decreasing salinity conditions and increasing euryhalinity with the predominance of $C$. torosa and a decrease in diversity. The peat horizon in this borehole (SS2-9) contains Ostracoda. Sample 8 contains five freshwater taxa in addition to the brackish water species.

The succeeding transgressive phase which began the Upper Clay deposition is characterised in this area by a series of channel sands in the 'Ab' Biofacies (samples 8-5). Here, the presence of the inner estuarine Haplophragmoides spp. indicates a nearby freshwater source. The environment is sub-tidal with typical channel faunas.

By sample 5 the final regression is seen starting with shallow water species becoming increasingly important. The final phase (samples 3-1) marks a return to mud deposition with increasing quantities of Phragmites debris added to the sediment. The channel here becomes a marsh channel before finally silting up. The five samples succeeding the peat horizon (7-3) are dominated by the two ostracod species most commonly observed in the estuary today (C. torosa and L. elliptica). The two uppermost samples, however, possess few specimens of $C$. torosa but other species such as Sclerochilus and a number of more marine taxa are recorded. Indeed, samples 5 through to 1 contain a number of instars of sub-littoral, open marine species e.g. Cytheropteron sp., Robertsonites tuberculatus, and Pontocythere elongata. These are interpreted as either reworked specimens from the surrounding estuarine sediments as the estuary silted up and/or the result of storm surges bringing in these small specimens.

The two boreholes described above, although taken 
within two kilometres of each other, show differences in the ostracod assemblages recovered. They both display the same peat/silty-mud alternations reflecting local sea-level and/or palaeogeographical changes. Both cores are dominated by brackish water mud dwellers, estuarine phytal species or shallow marine taxa. Core MHB1 has yielded moderately rich ostracod assemblages of low diversity, the majority representing in-situ populations. Core SS2, however, has a more diverse fauna. Many samples in the latter core contain species which are represented by only one or two specimens. These clearly represent an allochthonous element. It is assumed, therefore, that SS2 represents an environment where mixing of in situ and transported valves occurs. The faunal dichotomy between the two cores reflects the environmental differences which can occur within short distances in the estuarine setting.

\section{ENVIRONMENTAL INTERPRETATION OF CORES MHBI AND SS2}

A complete study of the many boreholes from this area have afforded a detailed reconstruction of the palaeogeographic history of this estuary. The Breydon Formation in the study area occupies a flat bottomed valley with relatively steep sides. MHB1 is sited approximately 300 metres due south of the northern margin of the valley which is marked by a palaeo-shoreline which is clearly visible today. Core SS2 is sited south of the River Bure, and towards the centre of the estuary.

In the early part of the Lower Clay the MHB1 site lay close to the shore. The estuary is interpreted as a drowned river valley, with a sub-tidal channel sweeping close to the shoreline at this point. Immediately to the south the estuary shallowed to low intertidal sand flats before deepening again in the area of core SS2.

At the end of Lower Clay times the main channel had moved further south to the position of the present River Bure. During the regressive phase the SS2 area shallowed first and has a deeper sequence of saltmarsh sediments (mainly channel infills). The MHB1 site was transformed into intertidal flats before shallowing into the fresh and brackish water peats of Middle Peat times.

The Middle Peat occupied the whole width of the valley at this point. The transgression which resulted in the deposition of the Upper Clay is presumed to have been initiated by the destruction of a sand barrier which lay across the mouth of the estuary (Coles \& Funnell, 1981). In the Upper Clay tidal flats are, once again, found on the northern margin of the valley (MHB1) although at a higher position in the section than seen in SS2. South of the River Bure the sedimentary sequence is dominated by somewhat deeper situated channel deposits. This is a reverse of the interpretation given for the Lower Clay in these two boreholes. With the formation of a new sand bar from the 10th century onwards, both sites gradually silt up.

\section{ACKNOWLEDGEMENTS}

The authors wish to thank Prof. Brian Funnell (UEA) for his useful comments regarding the manuscript. Ms. Sheila Davies and Mr. P. Judge (UEA) are thanked for their assistance with photography and the draughting of diagrams respectively. We wish to acknowledge financial support through the award of a Leverhulme Fellowship (I.B.) and The Natural Environment Research Council, Academic Mapping Project contract number F60/G2/32 (M.G.).

Manuscript received March 1992

Manuscript accepted November 1992

\section{REFERENCES}

Alderton, A. 1983. Flandrian vegetational history and sea-level change of the Waveney Valley. Unpublished Ph.D. Thesis. University of Cambridge. $379 \mathrm{pp}$.

Athersuch, J., Horne, D.J. \& Whittaker, J.E. 1989. Marine and Brackish Water Ostracoda. Synopsis of the British Fauna (New Series) 43. Brill, Leiden. 343pp.

Banner, F.T. \& Culver, S.J. 1978. Quaternary Haynesina n. gen. and Palaeogene Protelphidium Haynes; their morphology, affinities and distribution. Journal of Foraminiferal Research 8. (3) 177-207.

Boomer, I.D. in press. Ostracod shell chemistry studies in an East Anglian Estuary.

Brady, G.S. \& Robertson, D. 1870. The Ostracoda and Foraminifera of tidal rivers. Annals Magazine of Natural History. Ser. 4. Vol.vi. .133.

Brew, D.S. 1990. Sedimentary environments and Holocene evolution of the Suffolk estuaries. Unpublished Ph.D. Thesis. University of East Anglia. 284pp.

Brew, D.S., Funnell, B.M. and Kreiser, A. 1992. Sedimentary environments and Holocene evolution of the lower Blyth Estuary, Suffolk (England) and a comparison with other East Anglian valleys. Proceedings of the Geological Association. 103.

Coles, B.P.L. 1977. The Holocene Foraminifera and palaeogeography of Central Broadland. Unpublished Ph.D. Thesis. University of East Anglia. 344pp. 29pls.

Coles, B.P.L. \& Funnell, B.M. 1981. Holocene palaeoenvironments of Broadland, England. In: Nio, S-D., Shuttenhelm, R.T.E. and Van Weering, T.C.E. (Eds), Holocene marine sedimentation in the North Sea Basin. Special Publication of the International Association of Sedimentologists. 5. 123-131.

Culver, S.J. \& Banner, F.T. 1978. Foraminiferal assemblages as Flandrian palaeoenvironmental indicators. Palaeogeography, Palaeoclimatology, Palaeoecology. 24. 53-72.

Funnell, B.M. 1979. History and prognosis of subsidence and sealevel change in the lower Yare Valley, Norfolk. Bulletin of the Geological Society of Norfolk. 31. 35-44.

Godwin, M.L. in prep. a. The Holocene foraminiferal biozones of East Anglia. Ph.D. Thesis. University of East Anglia.

Godwin, M.L. in prep. $b$. The foraminiferal biozones and biofacies of the Breydon Formation (Holocene), Norfolk, England.

Miller, A.A.L., Scott, D.B. \& Medioli, F.S. 1982. Elphidium excavatum (Terquem): ecophenotypic versus subspecific variation. Journal of Foraminiferal Research. 12 (2) 116-144.

Murray, J.W. 1971. An Atlas of British Recent Foraminiferids Heinemann, London.

Murray, J.W. 1973. Distribution and Ecology of living benthic Foraminiferids. Heinemann, London.

Murray, J.W. 1979. British nearshore foraminiferids. Synopsis of the British Fauna (New series) 16. (eds. D.M. Kermack \& R.S.K. Barnes) Academic press, London.

Murray, J.W. 1991. The Ecology and Palaeoecology of Benthic Foraminifera. Longmans, London. 
$\begin{array}{lllllllllllllllllllllllll}1 & 2 & 4 & 5 & 6 & 8 & 9 & 10 & 11 & 12 & 13 & 14 & 15 & 16 & 17 & 18 & 19 & 20 & 21 & 22 & 23 & 24 & 25 & 26 & 27\end{array}$

\begin{tabular}{lrrrrrrrrrrrrrrrrrrrrrrrrrrr}
\hline C. torosa & 0 & 0 & 0 & 0 & 0 & 0 & 0 & 0 & 0 & 0 & 0 & 100 & 96 & 88 & 86 & 63 & 95 & 63 & 23 & 5 & 4.7 & 14 & 36 & 2 & 8.8 \\
L. castanea & 46 & 86 & 75 & 75 & 71 & 11 & 0 & 0 & 0 & 0 & 0 & 0 & 4.3 & 12 & 9.1 & 23 & 0 & 10 & 54 & 25 & 3.1 & 10 & 9.1 & 4 & 6.9 \\
L. elliptica & 0 & 0 & 0 & 0 & 0 & 0 & 0 & 0 & 0 & 0 & 0 & 0 & 0 & 0 & 0 & 3.5 & 0 & 0 & 0 & 0 & 0 & 4.1 & 0 & 0 & 0 \\
C. fisheri & 12 & 14 & 6.3 & 0 & 0 & 0 & 0 & 0 & 0 & 0 & 0 & 0 & 0 & 0 & 2.3 & 5.3 & 0 & 0 & 0 & 0 & 0 & 0 & 0 & 0 & 0 \\
L. lacertosa & 40 & 0 & 0 & 13 & 0 & 0 & 0 & 0 & 0 & 0 & 0 & 0 & 0 & 0 & 0 & 0 & 0 & 0 & 0 & 0 & 0 & 6.1 & 0 & 0 & 0 \\
L. rhomboidea & 0 & 0 & 0 & 13 & 0 & 0 & 0 & 0 & 0 & 0 & 0 & 0 & 0 & 0 & 2.3 & 3.5 & 5.3 & 27 & 23 & 70 & 91 & 49 & 36 & 44 & 61 \\
H. viridis & 0.9 & 0 & 0 & 0 & 0 & 0 & 0 & 0 & 0 & 0 & 0 & 0 & 0 & 0 & 0 & 0 & 0 & 0 & 0 & 0 & 0 & 0 & 0 & 0 & 0 \\
H. villosa & 0 & 0 & 13 & 0 & 14 & 67 & 0 & 0 & 0 & 0 & 0 & 0 & 0 & 0 & 0 & 0 & 0 & 0 & 0 & 0 & 0 & 6.1 & 18 & 42 & 15 \\
Xestoleberis sp. & 0 & 0 & 0 & 0 & 0 & 22 & 0 & 0 & 0 & 0 & 0 & 0 & 0 & 0 & 0 & 0 & 0 & 0 & 0 & 0 & 0 & 0 & 0 & 0 & 0 \\
H. albomaculata & 0 & 0 & 6.3 & 0 & 14 & 0 & 0 & 0 & 0 & 0 & 0 & 0 & 0 & 0 & 0 & 0 & 0 & 0 & 0 & 0 & 1.6 & 0 & 0 & 5.9 & 5.9 \\
H. psarmophila & 0 & 0 & 0 & 0 & 0 & 0 & 0 & 0 & 0 & 0 & 0 & 0 & 0 & 0 & 0 & 0 & 0 & 0 & 0 & 0 & 0 & 0 & 0 & 3 & 0 \\
S. striata & 0 & 0 & 0 & 0 & 0 & 0 & 0 & 0 & 0 & 0 & 0 & 0 & 0 & 0 & 0 & 1.8 & 0 & 0 & 0 & 0 & 0 & 0 & 0 & 0 & 0 \\
P. guttata & 0 & 0 & 0 & 0 & 0 & 0 & 0 & 0 & 0 & 0 & 0 & 0 & 0 & 0 & 0 & 0 & 0 & 0 & 0 & 0 & 0 & 10 & 0 & 0 & 2.9
\end{tabular}

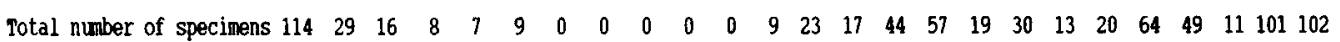
$\begin{array}{lllllllllllllllllllllllllll}\text { Number of species } & 4 & 2 & 4 & 3 & 3 & 3 & 0 & 0 & 0 & 0 & 0 & 1 & 2 & 2 & 4 & 6 & 2 & 3 & 3 & 3 & 4 & 7 & 4 & 6 & 6\end{array}$

Fig 5. Ostracod biostratigraphy of core MHB1 (per cent abundance).

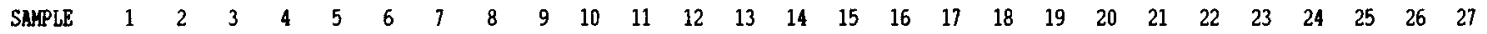

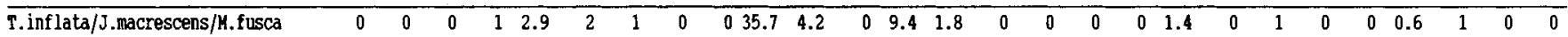

A.becarii var limnetes

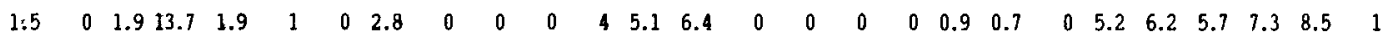

E. Hilliamsoni/E.excavatum forma lidoensis

H.germanicum

$\begin{array}{lllllllllllllllllllllllllllll}3.1 & 0 & 0 & 0 & 0 & 1 & 0 & 3.7 & 0 & 0 & 0 & 0 & 0 & 0 & 0 & 0.5 & 0 & 1 & 0 & 0 & 0 & 0 & 0 & 0 & 0 & 0 & 0\end{array}$

A. beccarii var tepida

$\begin{array}{lllllllllllllllllllllllllllll}13.1 & 21.1 & 12.4 & 25.5 & 9.2 & 5.8 & 2 & 24.1 & 50 & 28.6 & 14.4 & 56 & 27.6 & 13.6 & 17.5 & 11.9 & 10.4 & 11.7 & 12.2 & 10.3 & 16.7 & 14.4 & 34.7 & 6.9 & 28.4 & 0 & 4\end{array}$

A. becarii var batavus $\begin{array}{llllllllllllllllllllllllllll}2.3 & 0.7 & 0 & 5.9 & 1 & 1 & 0 & 5.6 & 0 & 28.6 & 0 & 0 & 0 & 0 & 1.1 & 0.4 & 0.9 & 0 & 0.4 & 0 & 0 & 2.9 & 0.6 & 3.1 & 2 & 0 & 0\end{array}$

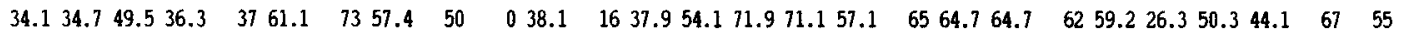

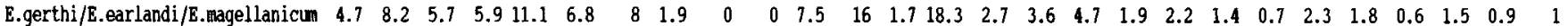
E. excavatum formas excavatum/

seiseyensis

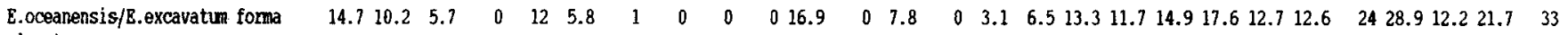
clavata

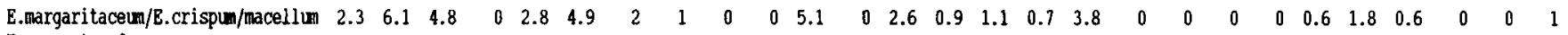
E.excavatum forma magna

H.depressula/E. incertur

SHELF ROTALIDS

MILIOLIDS

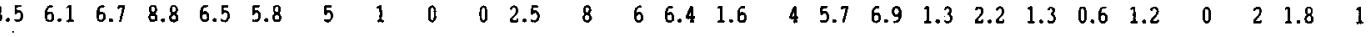
$\begin{array}{lllllllllllllllllllllllllll}5.4 & 5.4 & 7.5 & 2 & 9.3 & 2.9 & 4 & 2.8 & 0 & 7.1 & 7.6 & 0 & 0.9 & 0 & 0 & 0 & 0 & 0 & 0.9 & 1.5 & 1.3 & 1.1 & 0 & 1.3 & 1.5 & 0 & 3\end{array}$

$\begin{array}{llllllllllllllllllllllllllll}7.8 & 5.4 & 6.6 & 1 & 5.6 & 3.8 & 4 & 0 & 0 & 0 & 3.3 & 0 & 1.7 & 0.9 & 0.5 & 1.8 & 3.8 & 1 & 0.4 & 1.3 & 3.3 & 0.6 & 4.2 & 0 & 0 & 0 & 1\end{array}$

Planktonics/Cretaceous fossils

Total specimens in $10 \mathrm{~g}$ Total number of morphospecies

$\begin{array}{lllllllllllllllllllllllllllll}3 & 2 & 0 & 0 & 0 & 0 & 0 & 0 & 0 & 0 & 0 & 0 & 0 & 0 & 0 & 0 & 0 & 0 & 0 & 0 & 0 & 0 & 0 & 0 & 0 & 0 & 0\end{array}$

Fig 6. Foraminiferal biostratigraphy of core SS2 (per cent abundance).

Murray, J.W. \& Hawkins, A.B. 1976. Sediment transport in the Severn Estuary during the past $8000-9000$ years. Journal of the Geological Society of London. 132. 385-398.

Scott, D.B. \& Medioli, F.S. 1978. Vertical zonations of marsh Foraminifera as accurate indicators of former sea-levels. Nature. 272. 528-531.

Scott, D.B. \& Medioli, F.S. 1986. Foraminifera as sea-level indicators. In: Van de Plassche (Ed) Sea level research: A manual for the collection and evaluation of data. Geobooks, Norwich, U.K. 
Breydon Formation, palaeoenvironmental reconstruction

$\begin{array}{llllllllllllllllllllllllllll}\text { SAMPLE } & 1 & 2 & 3 & 4 & 5 & 6 & 7 & 8 & 9 & 10 & 11 & 12 & 13 & 14 & 15 & 16 & 17 & 18 & 19 & 20 & 21 & 22 & 23 & 24 & 25 & 26 & 27\end{array}$

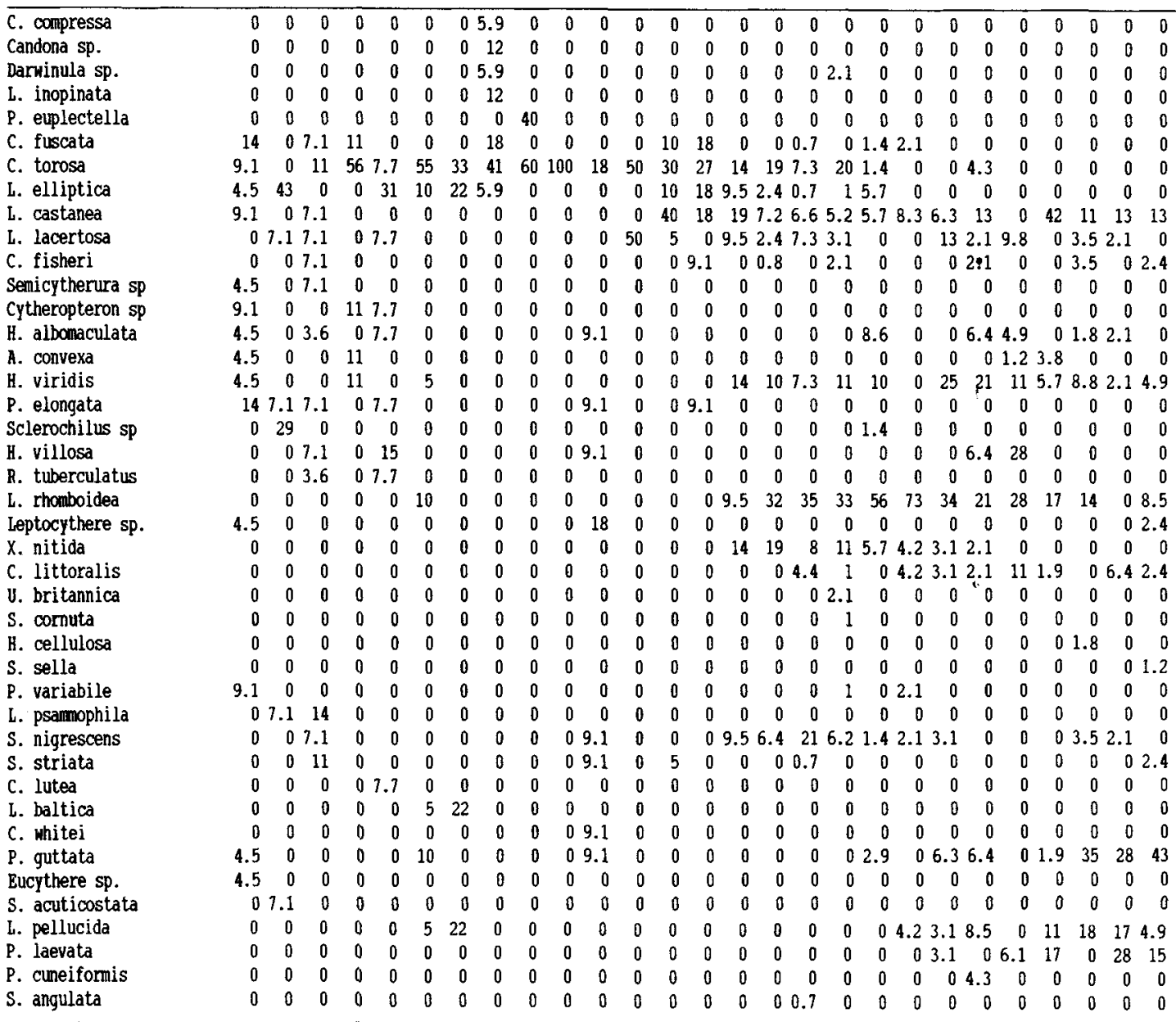

$\begin{array}{llllllllllllllllllllllllllllllllll}\text { Total number of specimens } & 22 & 14 & 28 & 9 & 13 & 20 & 9 & 17 & 5 & 5 & 11 & 2 & 20 & 11 & 21 & 125 & 137 & 97 & 70 & 48 & 32 & 47 & 82 & 53 & 57 & 94 & 82\end{array}$ Diversity $\begin{array}{llllllllllllllllllllllllllll}14 & 6 & 13 & 5 & 9 & 7 & 4 & 7 & 2 & 1 & 9 & 2 & 6 & 6 & 8 & 9 & 12 & 14 & 11 & 8 & 10 & 13 & 8 & 8 & 10 & 9 & 11\end{array}$

Fig 7. Ostracod biostratigraphy of core SS2 (per cent abundance). 